\title{
The Second Phase of Global Liquidity and Its Impact on Emerging Economies ${ }^{1}$
}

\author{
Hyun Song Shin \\ Princeton University
}

November 7, 2013

The term "global liquidity" is often invoked by emerging market policy makers to denote the global factor that drives cross-border spillovers in financial conditions and credit growth. The term is often used in connection with monetary policy spillovers from advanced economies.

However, global liquidity is not a term that would receive universal acknowledgement among researchers as being a meaningful concept. The vagueness of the word "liquidity" as well as its intellectual baggage associated with past academic disputes concerning the role of monetary aggregates in macroeconomics means that many listeners have already erected barriers to whatever comes next in the conversation. That said, the recent BIS report on global liquidity (BIS (2011), the "Landau report") and the IMF's work on the topic, both at the behest of the G20, have put the term "global liquidity" into the titles of official documents, and so it does appear that the term is here to stay. ${ }^{2}$

For the benefit of defining the issues more clearly, it is useful to distinguish two phases of global liquidity. The first phase, starting roughly in 2003 and lasting until the 2008 crisis, had global

\footnotetext{
${ }^{1}$ Keynote address at the Federal Reserve Bank of San Francisco Asia Economic Policy Conference, November 3-5, 2013. I thank Claudio Borio, Dietrich Domanski, Ingo Fender, Masazumi Hattori, Dong He, Philip Turner and Jing Yang for comments.

${ }^{2}$ See also the speeches on the subject by Caruana (2013a, 2013b) and the IMF working paper by Chen et al. (2012).
} 
banking at its center, and the central theme was the transmission of looser financial conditions across borders through the acceleration of banking sector capital flows. The global factor that explains comovements in financial conditions across geography and sectors in this context is the leverage of the global banks. This topic has been covered extensively (especially in the context of the European crisis), and so I will not dwell on it today. ${ }^{3}$

More relevant today is what I would classify as the Second Phase of Global Liquidity, which started around 2010. In this second phase, the main stage is the bond market, especially the market for emerging market debt securities that are open to international investors. As for the main players, the global banks have increasingly given way to asset managers and other "buy side" investors who have global reach. The transmission of financial conditions across borders has taken the form of "reaching for yield", the decline of risk premiums for debt securities and the explosion in issuance of international debt securities that has ensued in order to satisfy the demand.

Figure 1: Net "external" financing of emerging economies (source: Turner (2013))

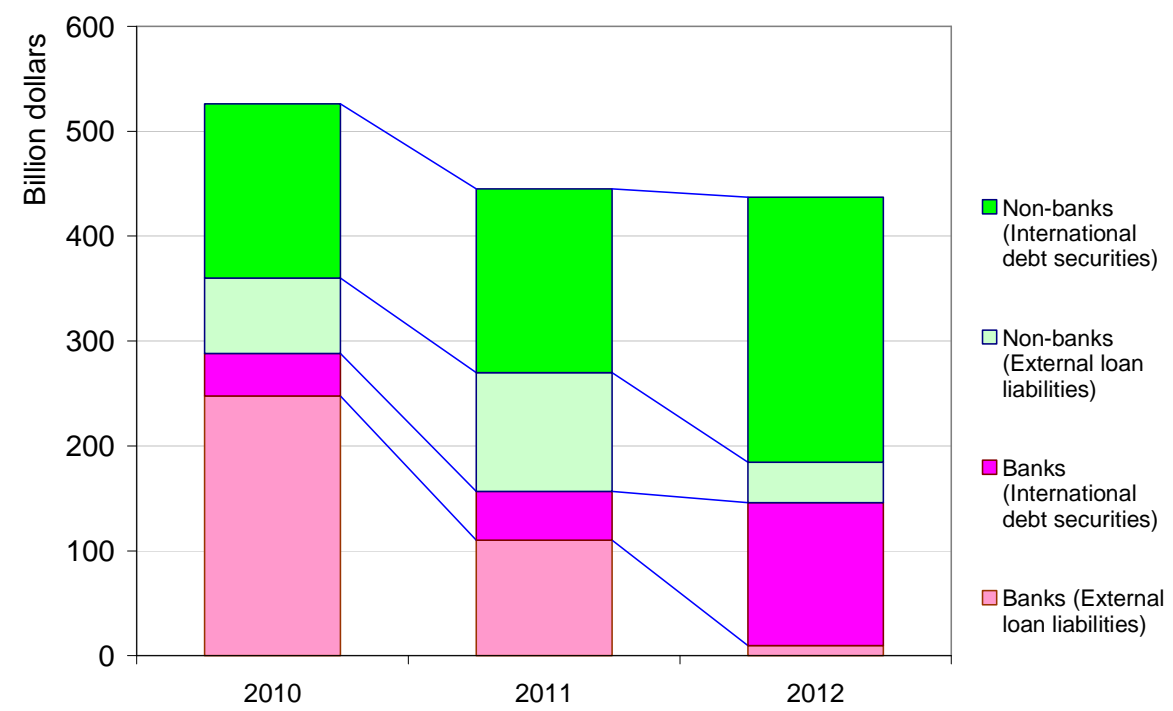

\footnotetext{
${ }^{3}$ See, for instance, the report of the Committee on International Economic Policy and Reform on "Banks and Capital Flows: Policy Challenges and Regulatory Responses" (CIEPR (2013)). I have previously characterized the First Phase of Global Liquidity as a "Banking Glut" (Shin (2012)). Bruno and Shin (2013) identify the leverage of global banks as the single global factor that drives financial conditions worldwide during the First Phase.
} 
Figure 1 summarizes the shift from banks to the bond market since 2010. The chart uses BIS banking and securities statistics and is taken from Turner (2013). The pink bars (both pale and deep pink) refer to borrowing by emerging market banks. The green bars refer to borrowing by non-banks. The numbers are net financing amounts each year, and hence denote increases in the amounts outstanding. Notice how the bottom pale pink bars shrink rapidly, indicating that the capital flows from global banks to emerging market banks have slowed to a trickle. In its place, emerging market banks have increased their debt securities issuance. For non-banks, the growth in net issuance of international debt securities has been even more dramatic.

Notice that in the legend for Figure 1, the word "external" is in inverted commas. This is because the international debt securities numbers in Figure 1 are based on the nationality of the borrower, rather than the usual practice of basing the classification on the residence of the borrower. If an emerging market corporate borrower issues US dollar-denominated bonds through its London subsidiary, the usual locational definition would treat the bonds as the liability of a UK entity. However, the emerging market company will manage its finances by reference to its consolidated balance sheet. Thus, in order to explain the behavior of the emerging market company, it is important to consider the consolidated balance sheet and take account of debt securities issued offshore.

Figure 2: International debt securities outstanding (all borrowers) by residence and nationality of issuer (source: BIS securities statistics Table 11A and 12A)
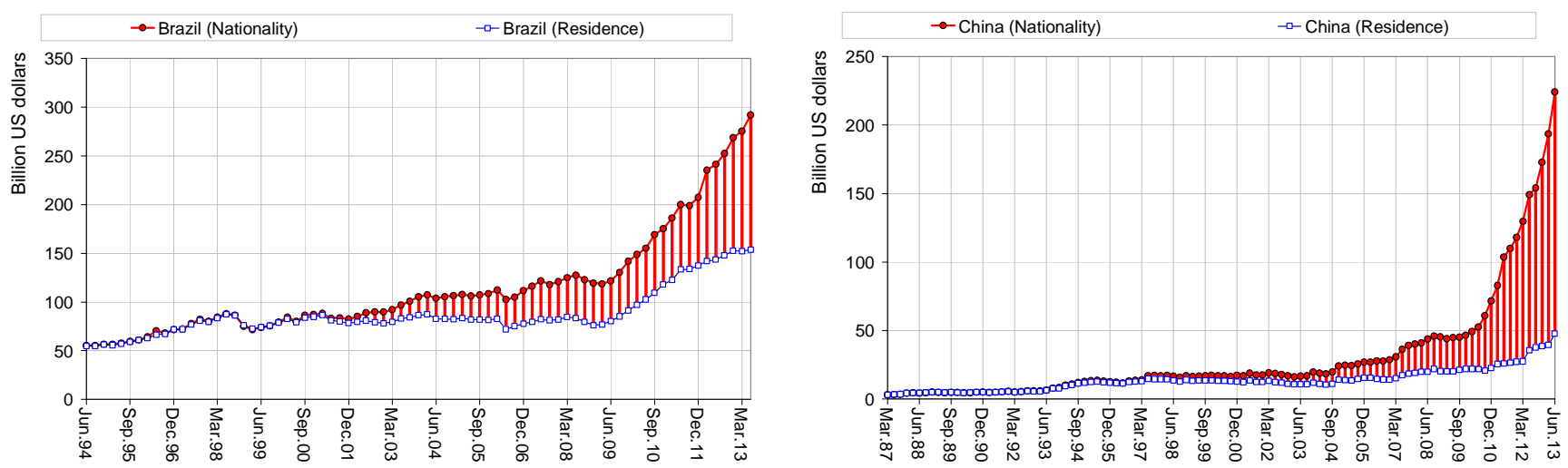

The offshore issuance of debt securities by emerging market firms has proceeded at great pace in recent years, as documented in the recent BIS Quarterly Review (McCauley, Upper and Villar (2013)). As an illustration, Figure 2 plots the international debt securities outstanding of 
borrowers from Brazil and China, plotted by residence and by nationality. The difference between the nationality and residence series is accounted for the offshore issuance of international debt securities. The difference remained small until after the global financial crisis, but since has widened dramatically. We can also see from the scale of the charts that the outstanding amounts are large. McCauley, Upper and Villar (2013) note that most of the offshore issuance has been in U.S. dollars, so that emerging market corporates have become much more sensitive to U.S. interest rates and the fluctuations in exchange rates vis-à-vis the U.S. dollar.

The weight of corporate bond issuance in offshore locations sheds light on a recent puzzle. The challenge has been to reconcile what appears to be the small net external debt position of many emerging economies (measured in the usual residence terms) with the apparently disproportionate impact of tighter global monetary conditions on their currencies and financial markets. ${ }^{4}$ One piece in the puzzle may be the role of non-financial firms that operate across borders. When corporate activity straddles the border, measuring exposures at the border itself may not capture the strains on corporate balance sheets.

Figure 3: Straddling the border through international transactions
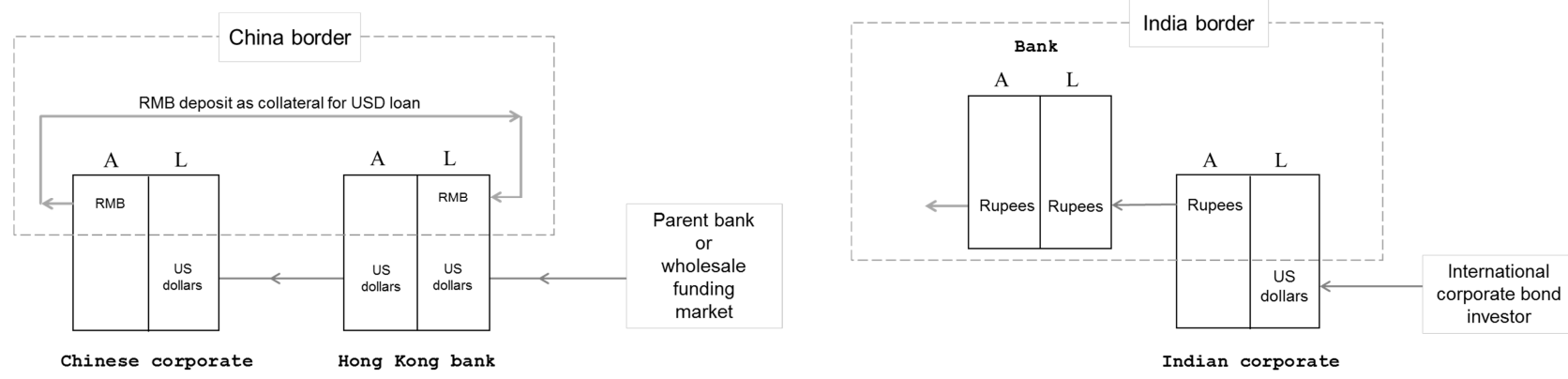

Figure 3 depicts two instances in which the true external exposures of firms with cross border activities may not be captured in the residence-based statistics. The left hand panel shows a Chinese corporate with a Hong Kong office who borrows in US dollars from a Hong Kong bank, and deposits RMB in the China office of the bank as collateral. This is just like the old London

\footnotetext{
${ }^{4}$ See, for instance Krugman (2013) "Rupee Panic" http://krugman.blogs.nytimes.com/2013/08/20/rupee-panic/
} 
Eurodollar currency swap transaction of the 1960s and 70s, which works like a straight collateralized loan. The right panel shows an Indian corporate which borrows in U.S. dollars through its London subsidiary and which defrays the group's costs using the dollars, but which then accumulates Rupees instead at headquarters. The Rupees are then held as time deposits in a local bank in India. In both instances, the firm has engineered a currency mismatch. In effect, the firm has taken on a carry trade position, holding cash in local currency financed with dollar liabilities.

One motive for taking on such a carry trade position may be to hedge U.S. dollar receivables. Alternatively, the carry trade position may be motivated by the prospect of financial gain if the domestic currency is expected to strengthen against the dollar. Whatever the motivation, the corporate treasurer who takes the consolidated balance sheet into account will care about fluctuations in the exchange rate as well as the U.S. dollar borrowing costs.

In this way, the Second Phase of Global Liquidity has resulted in a combination of forces that has increased the vulnerability of emerging economies to a reversal of permissive financial conditions. There are three elements:

- Yields on emerging market debt securities in local currency have fallen in tandem with those of advanced economies and have shown increasing tendency to move in sync with those of advanced economy bonds (Miyajima, Mohanty and Chan (2012), Turner (2013)).

- Offshore issuance of corporate bonds in foreign currency has resulted in currency mismatch on the consolidated balance sheets of emerging market firms. Accompanying the offshore issuance has been the growth in corporate deposits in the domestic banking system that are vulnerable to withdrawal in the event of corporate distress.

- The growing stock of emerging market corporate debt securities has been absorbed by asset managers whose main reason for buying them has been the perception of stronger economic fundamentals of emerging markets.

The reversal of all three elements during the summer of 2013 put emerging economy financial markets under severe stress. When the current lull in global financial conditions is eventually broken by tighter U.S. dollar funding conditions due to Federal Reserve monetary tightening, the 
vulnerabilities are likely to be exposed once more. Given the elements that have underpinned the Second Phase of Global Liquidity, the crisis dynamics in the emerging economies would then have the following elements:

1. Steepening of local currency yield curve

2. Currency depreciation, corporate distress, and runs of wholesale corporate deposits from the domestic banking system

3. Decline in corporate capital expenditure feeding directly into a slowdown in economic growth

4. Asset managers cutting back positions in EME corporate bonds citing slower growth in the emerging economies

5. Back to Step 1, thereby completing the loop.

The distress dynamics sketched above has some unfamiliar elements. We normally invoke either leverage or maturity mismatch when explaining crises and the usual protagonists in the crisis narrative are banks or other financial intermediaries. In contrast, the scenario sketched above has asset managers at its heart. We find this unsettling, as long-only investors are meant to be benign, not create vulnerability. They are routinely excluded from the list of "systemic" market participants.

However, the distinction between leveraged institutions and long-only investors matters less if they share the same tendency toward procyclicality. Asset managers are answerable to the trustees of the fund that have given them their mandate. In turn, the trustees are themselves agents vis-à-vis the ultimate beneficiaries. In this way, asset managers lie at the end of a chain of principal-agent relationships that may induce restrictions on their discretion to choose their portfolio. Frequently, the trading restrictions are based on measures of risk, used by banks and other leveraged players. As such, their behavior may exhibit the same type of procyclical risktaking that banks are known for. The uncomfortable lesson is that asset managers may not conform to the textbook picture of long-term investors, but instead may have much in common with banks in amplifying shocks. 
In addition, the large weight of the asset management sector in the financial system will ensure that any tendency toward procyclicality will be felt more broadly. The recent report by the U.S. Treasury's Office of Financial Research (OFR (2013)) estimates that the top five asset managers (BlackRock, Vanguard, State Street, Fidelity and Pimco) have combined assets under management (AUM) of $\$ 12$ trillion, while the top 10 have a combined AUM of $\$ 18$ trillion. As large as these figures are, they may underestimate total exposures to risk assets in that "assets under management" refers to equity, not total assets of these entities. Not much is known about the effective leverage of the asset management sector, but the leverage may be expected to be modest in the aggregate.

Given the potential for procyclical actions and the sheer size of the asset management sector, the usual indicators of vulnerability that were designed and back-tested for past crises (many of whom are bank-driven events), will no longer be very useful. In particular, the crisis indicators that were developed by reference to the First Phase of Global Liquidity will be of little use during the Second Phase of Global Liquidity. For instance, it would be easy for some policy makers to be lulled into a false sense of security by seeing that banking sector leverage is lower now than it was before the Lehman bankruptcy. As always, the challenge should be to anticipate the next crisis rather than looking back to the past crisis, but accountability exercises usually address known past weaknesses, rather than asking where the new dangers are.

What then are the useful signals for vulnerability during the Second Phase of Global Liquidity? Tracking the amounts outstanding of corporate bonds and the yields on such bonds would be a good first step. Tracking offshore issuance by emerging market borrowers may be particularly informative in gaining a sense of the currency mismatch on the consolidated balance sheet.

There is one further idea, which harks back to the classic theme of measuring global monetary aggregates. This brings us back full circle to "global liquidity" in the title. The key insight is that any corporate bond issuance activity will leave an imprint on the domestic banking system. Since the firm will be issuing more debt during periods of permissive financial conditions in international capital markets, increased borrowing in international capital markets will coincide 
with greater holdings of cash as deposits in the banking system or short-term instruments in the shadow banking system. ${ }^{5}$

Thus, an indirect way to track the activity of corporates who straddle the border is to examine the fluctuations in a monetary aggregate consisting of the corporate deposits and other claims of the non-financial corporate sector on the domestic banking system.

In recent work with some co-authors ${ }^{6} \mathrm{I}$ have examined the properties of such an aggregate by constructing a global monetary aggregate that consists only of claims of non-financial corporates. The procedure is as follows. For each country $j$, we take the deposits of non-financial corporates in the banking system from the information that is used to compile the IMF's International Financial Statistics (IFS). Having obtained corporate deposits $L_{j}$ for each country, we convert the sum into U.S. dollars and then add up across countries. The resulting series is dubbed $G L$ where "GL" stands for "Global Liquidity". In other words, GL is defined as follows.

$$
G L=\sum_{j} \frac{L_{j}}{\text { Price of U.S. dollars in currency of country } j}
$$

The study of global monetary aggregate echoes the project outlined by McKinnon (1982), but with a very different rationale. McKinnon (1982) proposed a global monetary aggregate in a monetarist framework with a stable demand for global money due to the possibility of substitution between currencies. For us, the role of the money stock serves as an indirect indicator of global credit conditions when the cross-border activity of non-financial firms makes the direct measurement of corporate credit through standard locational measures of external indebtedness less meaningful.

\footnotetext{
${ }^{5}$ An example is Japan in the 1980s. Hattori, Shin and Takahashi (2009) show that the rapid increase in broad money in Japan in the 1980s was due to corporate time deposits of large manufacturing firms recycling capital market funding.

${ }^{6}$ Chung, Lee, Loukoianova, Park and Shin (2013)
} 
Figure 4: Global broad money and Global Liquidity: levels (left panel) and annual growth rates (right panel)) (Source: Chung et al. (2013), data from IMF International Financial Statistics)

(2002Q4-2013Q1)
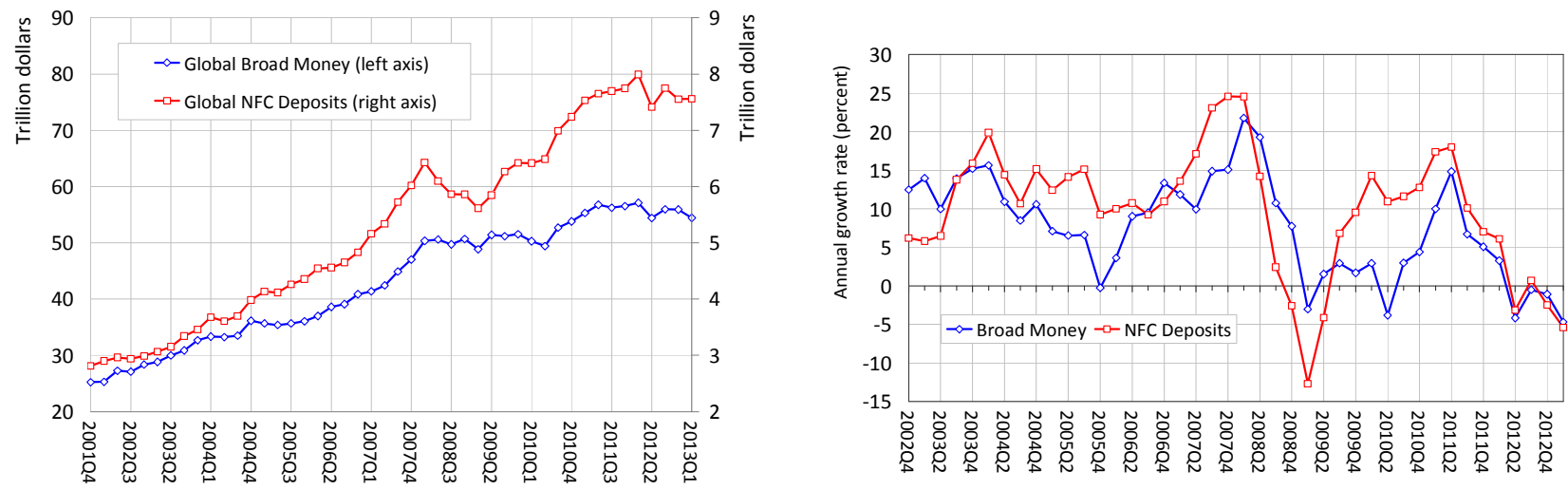

We see from Figure 4 that the global liquidity measure displays a highly procyclical pattern, tracking the upswing before the global financial crisis, the sharp decline with the onset of the global financial crisis, and then the subsequent recovery afterwards.

In Figure 4, the sharp fluctuations in the global liquidity measure reflect, in part, the exchange rate movements of the U.S. dollar vis-à-vis other currencies. The sharp decline in the global liquidity measure during the 2008 financial crisis is explained in part by the rapid appreciation of the U.S. dollar that coincided with the deleveraging pressures that hit borrowers around the world. In turn, the bounce-back in the global liquidity measure reflects, in part, the appreciation of emerging economy currencies in the aftermath of the crisis. By using the U.S. dollar as the numeraire, the fluctuations in $G L$ due to exchange rate changes move in the same direction as the local currency quantities. So, the global liquidity aggregate reflects the reinforcing interaction of the exchange rate and the local currency monetary aggregates.

Chung et al. (2013) show that the global liquidity aggregate $G L$ co-moves strongly with global activity indicators, such as global exports, imports and GDP growth. Further investigations may reveal how much $G L$ tells us about vulnerability to crises. 


\section{References}

Bank for International Settlements (2011) "Global liquidity - concept, measurement and policy implications" CGFS Papers 45, Committee on the Global Financial System http://www.bis.org/publ/cgfs45.pdf

Bruno, Valentina and Hyun Song Shin (2013) "Capital Flows, Cross-Border Banking and Global Liquidity", NBER working paper w19038.

Caruana, Jaime (2013a) "Global liquidity: where do we stand?" speech at the Bank of Korea annual conference, Seoul, 4 June 2013, http://www.bis.org/speeches/sp130604.pdf

Caruana, Jaime (2013b) "Debt, global liquidity and the challenges of exit" speech at 8th FLARCAF, Cartagena, Colombia, 8 July 2013, http://www.bis.org/speeches/sp130708.pdf

Chung, Kyuil, Jong Eun Lee, Elena Loukoianova, Hail Park, and Hyun Song Shin (2013)

"Global Liquidity through the Lens of Monetary Aggregates" working paper

Chen, Sally, Philip Liu, Andrea Maechler, Chris Marsh, Sergejs Saksonovs, and Hyun Song Shin (2012) "Exploring the Dynamics of Global Liquidity" IMF working paper, 12/246, http://www.imf.org/external/pubs/ft/wp/2012/wp12246.pdf

Committee on International Economic Policy and Reform (2013) "Banks and Capital Flows: Policy Challenges and Regulatory Responses" http://www.brookings.edu/research/reports/2012/09/ciepr-banks-capital-flows

Hattori, Masazumi, Hyun Song Shin, and Wataru Takahashi (2009) "A Financial System Perspective on Japan's Experience in the Late 1980s," Bank of Japan IMES discussion paper, http://www.imes.boj.or.jp/english/publication/edps/2009/09-E-19.pdf

McCauley, Robert, Christian Upper and Agustín Villar (2013) "Emerging market debt securities issuance in offshore centres" BIS Quarterly Review, September, 22-23

McKinnon, Ronald I., 1982, "Currency Substitution and Instability in the World Dollar Standard," American Economic Review, Vol. 72, No. 3, 320-33

Miyajima, Ken, M. S. Mohanty and Tracy Chan (2012) "emerging market local currency bonds: diversification and stability" BIS working papers, no 391.

Office of Financial Research (2013) "Asset Management and Financial Stability" http://www.treasury.gov/initiatives/ofr/research/Documents/OFR AMFS FINAL.pdf

Shin, Hyun Song (2012) "Global Banking Glut and Loan Risk Premium" Mundell-Fleming Lecture, IMF Economic Review 60 (2), 155-192.

Turner, Philip (2013) "The global long-term interest rate, financial risks and policy choices in EMEs", paper for the Inter-American Development Bank Meeting of Chief Economists of Central Banks and Finance Ministries, Washington DC, October 2013. 